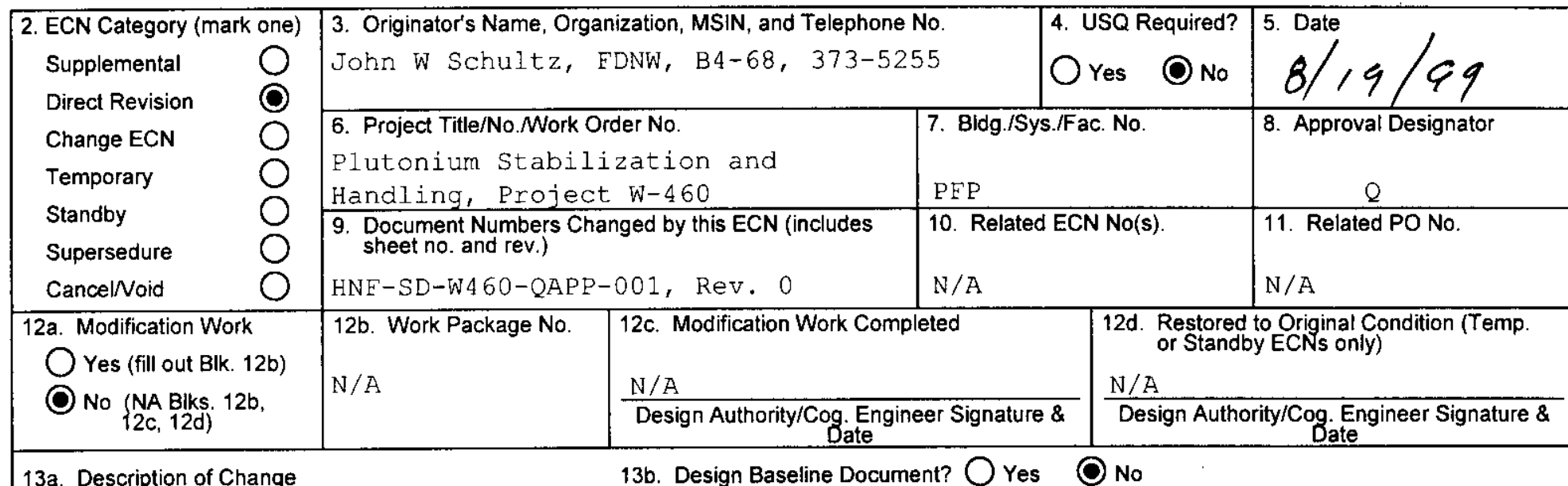

Revise HNF-SD-W460-QAPP-001, Revision 0, in its entirety, to incorporate changes in Scope, Responsibilities, miscellaneous sections relating to the Quality Assurance Programmatic requirements, and identification of critical components affected by the project. The layout of the QAPD Implementation Matrix has also been modified to reflect the location where Quality affecting procedures can be found.

14a. Justification (mark one)
Criteria Change
Design Improvement
Environmental
Facility Deactivation
As-Found
Facilitate Const.
Const. Error/Omission
Design Error/Omission

15. Distribution (include name, MSIN, and no. of copies)

Sh Johnston, B4-09, 7 See attached distribution 1 ist.

WA Halstein, $\mathrm{H} 6-03,1$

DW Nelson, $16-03,1$

JW Schultz, B4-68, 1

EV Woiss, $\mathrm{H} 6-\mathrm{Q}, 1$

sheller, T4-15, 1 . 14b. Justification Details

Modifications required to be consistent with changes being made to the Functional Design Criteria and the elimination of the BNFL Stabilization and Packaging system (SPS) for this project. 
ENGINEERING CHANGE NOTICE

Page 2 of 2

1. $E C N$ (use no. from pg. 1)

651584

16. Design Verification

Required

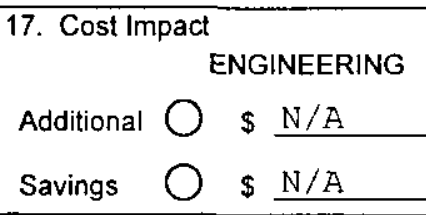

CONSTRUCTION
Y Yes
ONo

Savings

$\$ N / A$

$+2$

Additional

$\$ N / A$

) $\$ N / A$

18. Schedule Impact (days)

19. Change Impact Review: Indicate the related documents (other than the engineering documents identified on Side 1) that will be affected by the change described in Block 13. Enter the affected document number in Block 20.

$\begin{array}{lll}\text { SDD/DD } & \text { Seismic/Stress Analysis } \\ \text { Functional Design Criteria } & \square & \text { Stress/Design Report } \\ \text { Operating Specification } & \square & \text { Interface Control Drawing } \\ \text { Criticality Specification } & \square & \text { Calibration Procedure } \\ \text { Conceptual Design Report } & \square & \text { Installation Procedure } \\ \text { Equipment Spec. } & \square & \text { Maintenance Procedure } \\ \text { Const. Spec. } & \square & \text { Engineering Procedure } \\ \text { Procurement Spec. } & \square & \text { Operating Instruction } \\ \text { Vendor Information } & \square & \text { Operating Procedure } \\ \text { OM Manual } & \square & \text { Operational Safety Requirement } \\ \text { FSAR/SAR } & \square & \text { IEFD Drawing } \\ \text { Safety Equipment List } & \square & \text { Cell Arrangement Drawing } \\ \text { Radiation Work Permit } & \square & \text { Essential Material Specification } \\ \text { Environmental Impact Statement } & \square & \text { Fac. Proc. Samp. Schedule } \\ \text { Environmental Report } & \square & \text { Inspection Plan } \\ \text { Environmental Permit } & \square] & \text { Inventory Adjustment Request }\end{array}$

$\square$
$\square$
$\square$
$\square$
$\square$
$\square$
$\square$
$\square$
$\square$
$\square$
$\square$
$\square$
$\square$
$\square$
$\square$
$\square$

Tank Calibration Manual Health Physics Procedure Spares Multiple Unit Listing Test Procedures/Specification Component Index ASME Coded Item Human Factor Consideration Computer Software Electric Circuit Schedule ICRS Procedure Process Control Manual/Plan Process Flow Chart Purchase Requisition Tickler File N/A

$0 \frac{N / A}{N / A}$

20. Other Affected Documents: (NOTE: Documents listed below will not be revised by this ECN.) Signatures below indicate that the signing organization has been notified of other affected documents listed below.

Document Number/Revision $N / A$
Document Number/Revision

Document Number/Revision

21. Approvals

Signature

Design Authority Nor $x$ ds $/ c x$ \$118/99

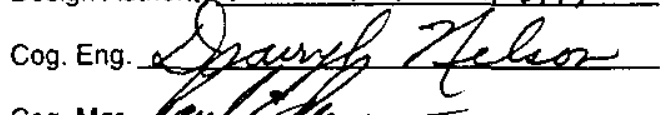

Cog. Mgr. $\mathrm{Cenlls}$

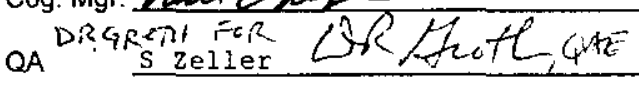

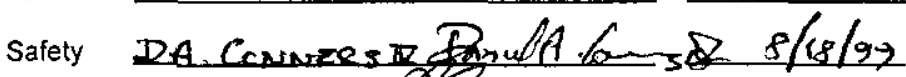

Environ. 1.E.Groms-
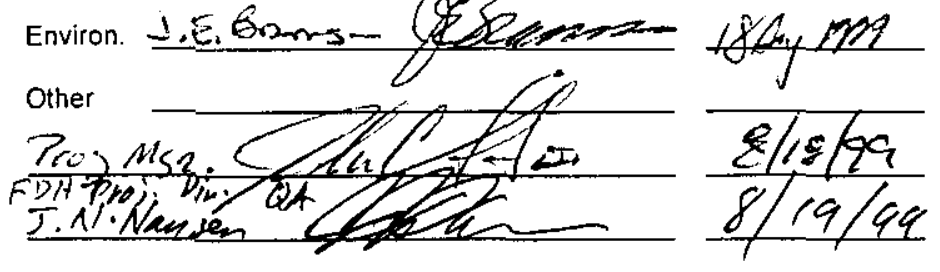

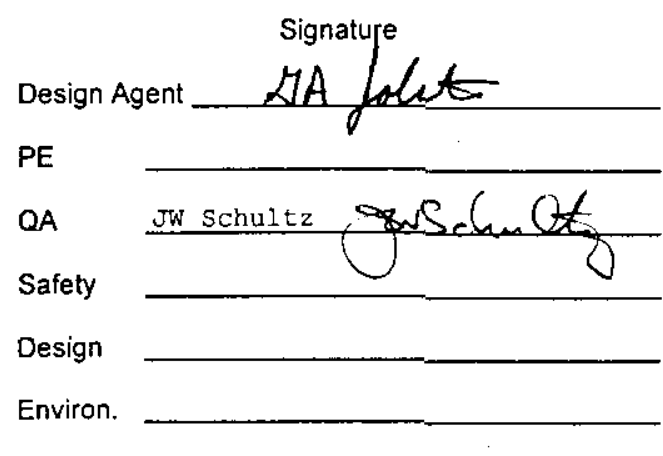

Other

\section{DEPARTMENT OF ENERGY}

Signature or a Control Number that tracks the Approval Signature
Date $8-16-99$

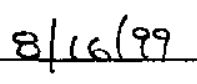

\section{ADDITIONAL.}




\section{DISTRIBUTION SHEET}

To

Distribution

Project Title/Work Order

Quality Assurance Program Plan-Plutonium Stabilization and Handling Project $W-460$

\begin{tabular}{|l|l|}
\hline \multicolumn{1}{|c|}{ Name } & \\
\hline Larry D Romine & \\
\hline David J Sherwood & \\
\hline George Dragseth & \\
\hline Larry J Olguin & \\
\hline George W Reddick Jr. & \\
\hline George M McGrath & \\
\hline Fred R Crawford & \\
\hline John C Sinclair III & \\
\hline William A Holstein Sr. & \\
\hline Darryl W Nelson & \\
\hline Paul E Roege & \\
\hline Jeff E Bramson & \\
\hline Ron R Allen & \\
\hline Leslie L Reed & \\
\hline Shirley Zeller & \\
\hline Thomas W Campbell & \\
\hline Dennis P Hughes & \\
\hline Jerry A Johnston & \\
\hline Charles T O'Neill & \\
\hline John W Schultz & \\
\hline Central Files & \\
\hline RL Reading Room & \\
\hline & \\
\hline
\end{tabular}

From

Darryl Nelson

ECN No. 651584

\begin{tabular}{|c|c|c|c|c|}
\hline MSIN & $\begin{array}{c}\text { Text } \\
\text { With All } \\
\text { Attach. }\end{array}$ & Text Only & $\begin{array}{l}\text { Attach./ } \\
\text { Appendix } \\
\text { Only }\end{array}$ & $\begin{array}{c}\text { EDT/ECN } \\
\text { Only }\end{array}$ \\
\hline R3-79 & & & & $\mathrm{x}$ \\
\hline R3-79 & $x$ & & & \\
\hline$A 5-18$ & $x$ & & & \\
\hline L5 -65 & & & & $\mathrm{x}$ \\
\hline L5-65 & & & & $x$ \\
\hline$L 5-65$ & $\mathrm{x}$ & & & \\
\hline T $5-50$ & & & & $\mathrm{x}$ \\
\hline T5-50 & & & & $\mathrm{x}$ \\
\hline $\mathrm{H} 6-03$ & $\mathrm{x}$ & & & \\
\hline H6-03 & $x$ & & & \\
\hline T5-57 & $x$ & & & \\
\hline T5-54 & & & & $x$ \\
\hline T5-11 & & & & $\mathrm{X}$ \\
\hline T5-57 & & & & $x$ \\
\hline$T 4-15$ & $x$ & & & \\
\hline$S 2-46$ & & & & $\mathrm{X}$ \\
\hline T5-50 & & & & $\mathrm{x}$ \\
\hline B4-09 & & & & $x$ \\
\hline B4 -39 & & & & $x$ \\
\hline$B 4-68$ & $x$ & & & \\
\hline B1-07 & $\mathrm{x}$ & & & \\
\hline H2 -53 & $\mathrm{X}$ & & & \\
\hline
\end{tabular}




\section{QUALITY ASSURANCE PROGRAM PLAN - PLUTONIUM STABILIZATION AND HANDLING PROJECT W-460}

John W. Schultz

FDNW

Richland, WA 99352

U.S. Department of Energy Contract DE-AC06-96RL13200

$\begin{array}{lll}\text { EDT/ECN: } & 651584 & \text { UC: } 2050 \\ \text { Org Code: } & 15 \mathrm{C} 00 & \text { Charge Code: } 100775 \mathrm{BA30} \mu \mathrm{HN990031} \\ \text { B\&R Code: } & 39 \mathrm{Ew} 70400 & \text { Total Pages: } 24\end{array}$

Key Words: Stabilization and Packaging, SPE, Plutonium, Glovebox, Furnaces, Welding, DNESB 94-1, 94-1, 3013-96, PuSH, SNM, FDC, W460, Quality Assurance Program Plan, QAPP, QA

Abstract: This Quality Assurance Program Plan (QAPP) identifies Project Quality Assurance (QA) program requirements for all parties participating in the design, procurement, demolition, construction, installation, inspection and testing for Project $w-460$.

TRADEMARK DISCLAIMER. Reference herein to any specific commercial product, process, or service by trade name, trademark, manufacturer, or otherwise, does not necessarily constitute or imply its endorsement, recommendation, or favoring by the United States Government or any agency thereof or its contractors or subcontractors.

Printed in the United States of America. To obtain copies of this document, contact: Document Control Services. P.O. Box 950, Mailstop H6-08, Richland WA 99352, Phone (509) 372-2420; Fax (509) 376-4989.

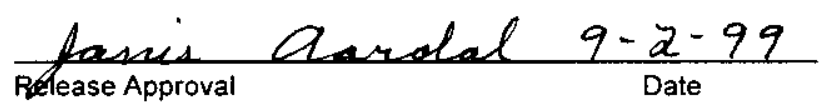

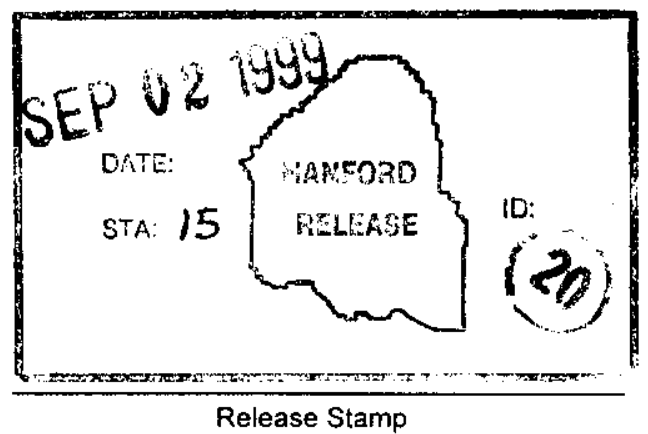

Release Stamp 


\section{RECORD OF REVISION}

\begin{tabular}{|l|l}
$\begin{array}{l}\text { (1) Document Number } \\
\text { HNF-SD-W460-QAPP-001 }\end{array}$ & Page 1 \\
\hline
\end{tabular}

(2) Title

Quality Assurance Program Plan, B\&W Hanford Co. and Fluor Daniel Northwest, Plutonium Stabilization and Handling, Project $w-460$

Change Control Record

(3) Revision

0

1 RS
(4) Description of Change - Replace, Add, and Delete Pages

(7)

Initial Issue per EDT 617726

Direct Revision per ECN 651584 to incorporate changes based on FDC Revision.
Authorized for Release

\begin{tabular}{l|ll} 
(5) Cog. Engr. & (6) Cog. Mgr. $\quad$ Date \\
\hline
\end{tabular}

EV Weiss

TE Huber $4 / 17 / 98$

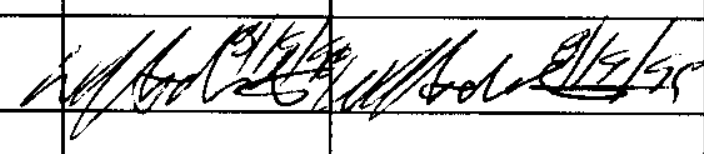

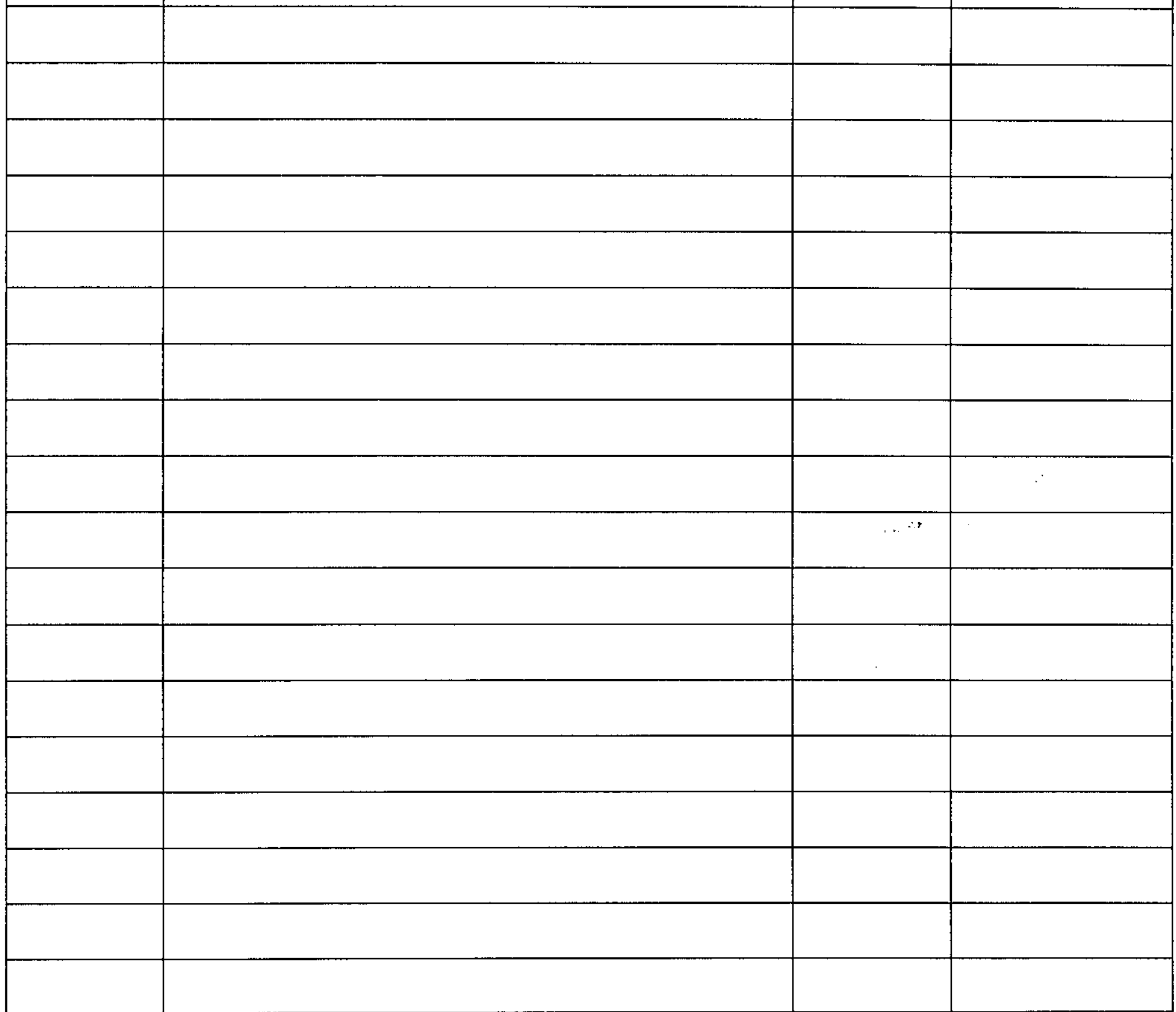


Project Hanford Management Contract

\title{
QUALITY ASSURANCE PROGRAM PLAN
}

\author{
$B \& W$ Hanford Co. \\ and
}

Fluor Daniel Northwest

Plutonium Stabilization and Handling

Project W-460

HNF-SD-W460-QAPP-001

Revision 1

B\&W HANFORD Co.

August 1999 


\title{
B\&W Hanford Co.
}

\author{
Plutonium Finishing Plant
}

\section{QUALITY ASSURANCE PROGRAM PLAN}

\author{
Plutonium Stabilization and Handling \\ Project W-460
}

\section{Approvals:}

Approvals are Located on ECN $\underline{651584}$

Prepared by:

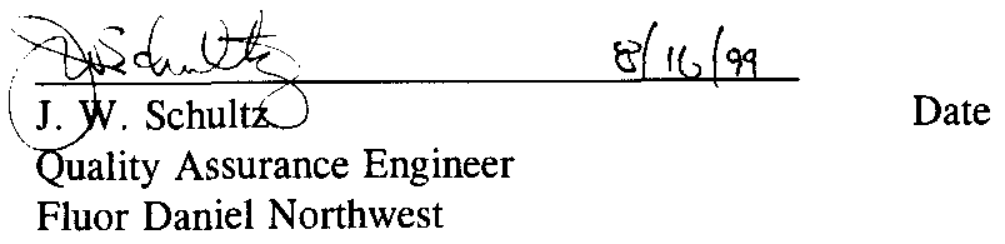




\section{Table of Contents}

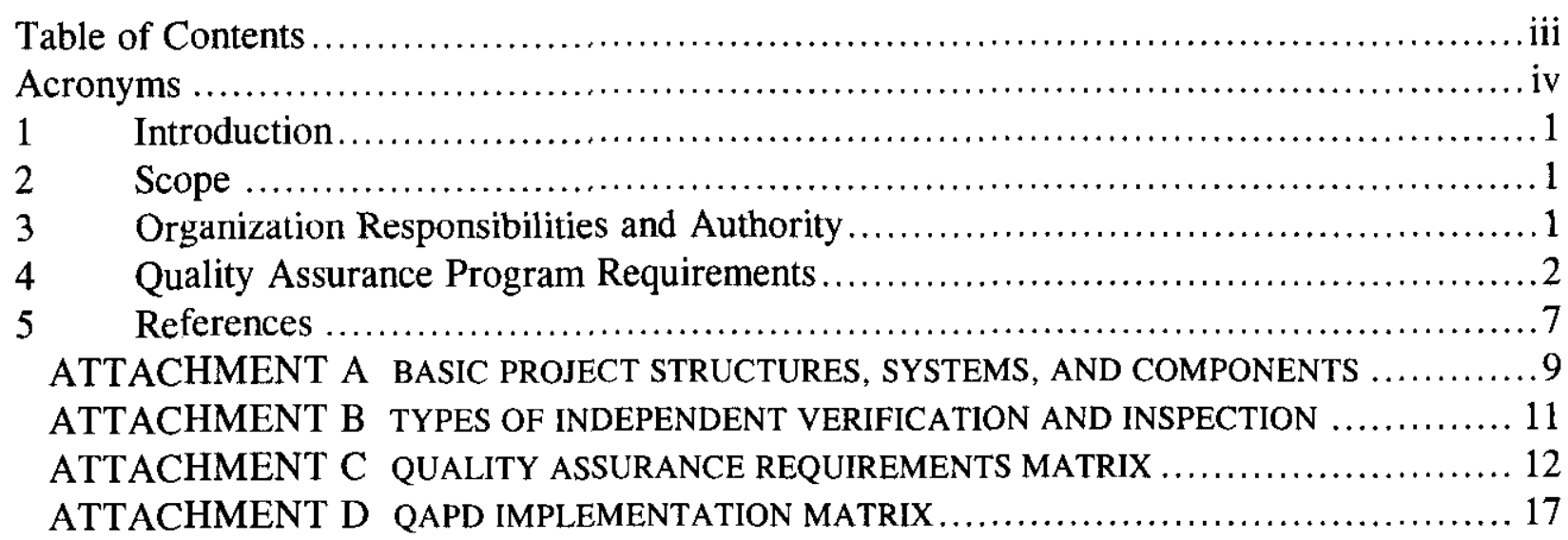


Acronyms

$\begin{array}{ll}\text { A-E } & \text { Architect-Engineering } \\ \text { AI } & \text { Acceptance Inspection } \\ \text { ASME } & \text { American Society of Mechanical Engineers } \\ \text { BTC } & \text { Bagless Transfer Container } \\ \text { BTS } & \text { Bagless Transfer System } \\ \text { BWHC } & \text { B\&W Hanford Co. } \\ \text { CFR } & \text { Code of Federal Regulation } \\ \text { CM } & \text { Construction Management } \\ \text { DOE-RL } & \text { Department of Energy, Richland Operations Office } \\ \text { ENCO } & \text { Enterprise Company } \\ \text { FS } & \text { Facility Stabilization } \\ \text { FDC } & \text { Functional Design Criteria } \\ \text { FDH } & \text { Fluor Daniel Hanford } \\ \text { FDNW } & \text { Fluor Daniel Northwest } \\ \text { GS } & \text { General Service } \\ \text { GFE } & \text { Government Furnished Equipment } \\ \text { MSC } & \text { Major Subcontractor } \\ \text { NDA } & \text { Non-Destructive Assay } \\ \text { NQA } & \text { Nuclear Quality Assurance } \\ \text { PEP/PPM } & \text { Project Execution Plan/Project Procedures Manual } \\ \text { PHMC } & \text { Project Hanford Management Contract } \\ \text { PHMS } & \text { Project Hanford Management System } \\ \text { PFP } & \text { Plutonium Finishing Plant } \\ \text { PM } & \text { Project Management } \\ \text { PMP } & \text { Project Management Plan } \\ \text { PSAR } & \text { Preliminary Safety Analysis Report } \\ \text { PuSH } & \text { Plutonium Stabilization and Handling } \\ \text { PSE } & \text { Preliminary Safety Evaluation } \\ \text { QA } & \text { Quality Assurance } \\ \text { QAPD } & \text { Quality Assurance Program Description } \\ \text { QAPP } & \text { Quality Assurance Program Plan } \\ \text { SAR } & \text { Safety Analysis Report } \\ \text { SC } & \text { Safety Class } \\ \text { SPE } & \text { Stabilization and Packaging Equipment } \\ \text { SRID } & \text { Standards/Requirements Identification Document } \\ \text { SS } & \text { Safety Significant } \\ \text { SSC } & \text { Structures, Systems, and Components } \\ \text { TBD } & \text { To Be Determined } \\ \text { WBS } & \text { Work Breakdown Structure } \\ \text { WHC } & \text { Westinghouse Hanford Company } \\ & \end{array}$




\section{Introduction}

1.1 Project W-460, Plutonium Stabilization and Handling, encompasses several related actions which will implement the provisions of Department of Energy (DOE) Standard DOE-STD-3013-96 (3013) for special nuclear material inventories of plutonium and plutonium/uranium oxides at Hanford's Plutonium Finishing Plant (PFP). The project will comply with the commitments of Defense Nuclear Facilities Safety Board Recommendation 94-1 to stabilize and package remaining plutonium for safe secure storage for up to fifty years. The Project will consolidate stabilization, packaging and storage functions into a single location within the PFP facility, the 2736-Z Complex. This will allow eventual deactivation of other PFP facility areas no longer needed while maintaining all functions required for safe storage. In addition to facility modifications to be designed, constructed and installed at the 2736-Z Storage Complex, the Project provides funding for Stabilization and Packaging Equipment (SPE), including a Bagless Transfer System (BTS) and other components which will be procured and supplied to the project as government furnished equipment (GFE).

\section{Scope}

2.1 This Quality Assurance Program Plan (QAPP) identifies Project Quality Assurance (QA) program requirements B\&W Hanford Co. (BWHC) and for Fluor Daniel Northwest (FDNW), an Enterprise Company (ENCO), a Major Subcontractor (MSC) under the Project Hanford Management Contract (PHMC). This QAPP is the consolidated QA Program document for BWHC and FDNW for the planning and execution of Hanford Site activities for design, procurement, demolition, construction, installation, inspection and testing for Project W-460. These efforts are for the stabilization glovebox equipment specification, the $2736-\mathrm{Z}$ vault modifications, NonDestructive Assay (NDA) laboratory modifications, and the general 2736-ZB facility modifications.

2.2 Specific details related to the total scope are identified in Project W-460, Plutonium Stabilization \& Handling, Project Execution Plan, HNF-4681. As the changes, that document will be the governing document over this Quality Assurance Program Plan for scope identification.

3 Organization Responsibilities and Authority

3.1 BWHC, the MSC, is responsible for overview of all quality related documentation for Project design, procurement, fabrication, installation, and construction. This overview will ensure conformance with the requirements of the Functional Design Criteria (FDC) based upon approved MSC procedures. For work performed by sub-tier contractors, the MSC overview is not based on the MSC procedures, rather it will be based on those contractor procedures. FDNW will adhere to PFP facility specific work controls and procedures that allow PFP Operations to maintain control of PFP Plant configuration and safety as directed in the contract documents. 
3.2 Responsible organizations performing Definitive Design Engineering, Engineering and Inspection during Construction, Procurement, Construction, and Project Management shall be identified within the confines of the Work Breakdown Structure (WBS) located in the Project Execution Plan (PEP). Specific responsibilities and interfaces are further defined in the PEP. If responsibilities are changed during the course of the project, these changes shall be made per approved MSC procedures.

\subsubsection{Fluor Daniel Hanford (FDH) Acceptance Inspection (AI) provides independent} construction inspection for DOE-RL to verify and document the effectiveness of the construction project's quality control program. The Acceptance Inspection Plan identifies the required inspection events and AI Holdpoints for the project. Acceptance Inspection performs the independent construction inspection/testing and source inspection/testing of construction workmanship, materials, and equipment for the purpose of evaluating conformity or nonconformity to the approved drawings and specifications. An Acceptance Inspection Plan will be required for the W-460 construction project. It is generated by FDH Acceptance Inspection and submitted to the DOE-RL Project Office for approval and subsequent transmittal to the BWHC Project Integrator prior to initiation of construction.

3.3 The Construction Contractor(s) and Vendor(s) are responsible and held accountable for their assigned work regarding project and procurement quality. The Construction Contractor and/or Vendor shall perform, or have performed, assigned quality verification activities as specified in procurement documents and identified in drawings, specifications and other approved Project documents.

\section{Quality Assurance Program Requirements}

4.1 Quality Assurance Program requirements are derived or based upon HNF-MP-599, "Project Hanford Quality Assurance Program Description" (QAPD), which defines the implementation of 10 CFR 830.120 . As this project affects a Nuclear Facility, the "Enforcement Applicability" of 10 CFR 830.120 is required and is addressed in the Foreword of the QAPD. The ten basic sections of the QAPD form the foundation for the requirements for all quality assurance activities. Each of these QAPD sections are identified further in paragraph 4.7. Application of the quality assurance program is based on the graded approach as noted in paragraphs 4.3 and 4.4. The Project Hanford Management System (PHMS) are the site wide policy and procedures which are utilized for BWHC activities. The QAPD, PHMS, company level procedures, facility level documents, and this project QAPP provide specific controls for work performance. The QAPD Implementation Matrix (Attachment D) identifies the location for the applicable implementing Project Hanford/BWHC procedures for performing work on Project W460. References to FDNW procedures are also included in the matrix. Note that only minimal QA related procedures are identified. The remaining FDNW procedures to be used are identified and/or included in the FDNW Facility Stabilization (FS) Project 
Execution Plan/Project Procedures Manual. The applicability of these procedures is a selective process dependent upon the work being performed and the safety significance of the activities.

\subsection{Quality Assurance Requirements Flowdown}

Applicable QA requirements shall be passed down from BWHC to sub-tier contractors (FDNW and Construction Contractors) through statements of work, task orders, definitive design media, and/or procurement documents, as applicable. Further instruction as to the extent of QA requirements derived from the QAPD, and the implementation of these requirements, based upon a graded approach are noted in paragraphs $4.3,4.4$, and 4.6 .

\subsection{Application of the Graded Approach}

The quality management program's focus on the controls and systems necessary to ensure the output quality as required by 10 CFR 830.120 . Quality controls and systems will be applied to Project W-460 activities using a graded approach. The graded approach will be used to determine the scope and degree of rigor of the application of these requirements; i.e., a process by which the level of analysis, level of documentation, level of verification and actions necessary to comply with requirements are defined. The graded application of the QA Program requirements will be based on a varying combination of the following:

(1) The nuclear safety application of the item or activity.

(2) The level of risk and impact associated with a failure or deficiency.

(3) The age, status, and condition of a facility, process, or an item.

(4) The history of problems at a facility, with a process, or an item.

(5) The adequacy of existing controlling documentation.

(6) The complexity of products or activities involved.

(7) The control of potential project delays and cost if failures or deficiencies occur.

\subsection{Exceptions to the QAPD}

No specific exceptions are taken to the requirements established by the QAPD, however, the applicability of elements of the QAPD, based upon a graded approach, has been identified in Attachment C, "Quality Assurance Requirements Matrix". Each of the QAPD, Part 2, Quality Management Processes, Implementing Requirements paragraphs identified within the QAPD have been evaluated for applicability to Project W-460 in five main areas: Project Management (PM) by BWHC, ArchitectEngineering (A-E) by FDNW, Construction Management (CM) by FDNW, Construction Contractor activities by FDNW and/or a Fixed Price Contractor, and the BTS and miscellaneous Glovebox Procurement activities. These evaluations are at a high level which will require further decision making based upon the applicable structure, system, or component's Safety Class, Safety Significant, or General Service 
designation. As such, the more explicit applicability to each QAPD paragraph will be made during the definitive design process.

\subsection{QAPD Implementation Matrix}

The QAPD Implementation Matrix (Attachment D) provides a roadmap from HNF-MP0599 (QAPD) requirements to selected Project Hanford Policy and Procedures, BWHC and FDNW procedures which may be utilized as part of the Project W-460 QAPP to perform applicable work activities. Application of PHMS, BWHC, and/or FDNW procedures will be based upon the type of work being performed and the safety significance of the work. The reference to the Plutonium Finishing Plant, Quality Assurance Program Plan, FSP-PFP-5-8, Volume 2, Section 15.1, Appendix B is to restrict duplication and potential errors between that document and this one.

4.6 Critical characteristics of products and safety classification

As part of the safety analysis process, a preliminary safety evaluation (PSE), Preliminary Safety Evaluation for Project W-460, Plutonium Stabilization and Handling (PuSH), HNF-SD-W460-PSE-001, was prepared for Project W-460. The PSE identified structures, systems, and components (SSCs) which were determined to be important to the safety functions (safety class or safety significant) of the project. From the PSE, safety class and safety significant SSCs were identified and will receive more rigorous quality controls and appropriate quality codes and standards selected and applied (i. e., application of graded approach). The critical characteristics will be incorporated into applicable design or operations documents, verified, inspected or tested as appropriate and results evaluated and documented. As a follow-up to the original PSE, the Project will have further safety analysis performed, as required by the Safety Analysis Process. Should inadequate quality requirements be noted on completed work, that portion of work will be controlled using the Nonconformance Reporting process. No portion of the completed installation may be tested or placed in service prior to completion of the safety analysis with the accompanying review of project documents to assure compliance to quality requirements.

\subsection{Elements of the Quality Assurance Program Description}

\subsubsection{Program}

Quality Assurance Programs (QAPs) shall be developed, implemented, and maintained where identified within contract documents such as: statements of work, task orders, procurement documents, and definitive design media.

Quality Assurance Program requirements for Project W-460 are to comply with applicable portions of QAPD Part 2, Section 1, Program. 


\subsubsection{Personnel Training and Qualifications}

Personnel shall be adequately trained and qualified to perform their assigned tasks.

Training and qualification program requirements for Project W-460 are to comply with applicable portions of QAPD, Part 2, Section 2, Personnel Training and Qualification.

\subsubsection{Quality Improvement}

Management shall ensure quality improvement processes are instituted for the prevention and detection of quality problems.

Quality improvement processes established for Project W-460 are to comply with applicable portions of QAPD, Part 2, Section 3, Quality Improvement.

\subsubsection{Documents and Records}

Documentation and records control processes shall be employed for documents which control quality affecting activities.

Documents and records generated, processed, and maintained for Project W-460 are to comply with applicable portions of QAPD Part 2, Section 4, Documents and Records.

\subsubsection{Work Processes}

Work processes shall be established which are defined and controlled by written policies, plans, procedures, drawings, or other means to ensure the quality required for Project W-460.

Implementing procedures used on Project W-460 shall comply with applicable portions of QAPD Part 2, Section 5, Work Processes.

\subsubsection{Design}

Design activities shall be adequately controlled so that structures, systems, and components meet the applicable requirements and performance criteria established for Project W-460.

Design processes instituted for Project W-460 shall comply with applicable portions of QAPD Part 2, Section 6, Design. 


\subsubsection{Procurement}

Procurement processes shall adequately ensure structures, systems, components, or other items and services procured meet the appropriate technical and quality requirements established for Project W-460.

Procurement processes established for Project W-460 shall comply with applicable portions of QAPD Part 2, Section 7, Procurement.

\subsubsection{Inspection and Acceptance Testing}

Inspection and acceptance testing processes shall adequately ensure structures, systems, components, or other items procured, fabricated, or installed meet established design performance and quality requirements.

Processes for inspection and acceptance testing for Project W-460 shall comply with applicable portions of QAPD Part 2, Section 8, Inspection and Acceptance Testing.

\subsubsection{Management Assessment}

Management assessment processes shall be established to adequately address the achievement of strategic goals and the meeting of applicable standards related to Project W-460.

Management assessment processes for Project W-460 shall comply with the applicable portions of QAPD Part 2, Section 9, Management Assessment.

\subsubsection{Independent Assessment}

BWHC, FDNW and applicable sub-tier contractor personnel are responsible for cooperating with FDH independent assessment personnel in planning, preparation, and performance of assessments. BWHC and lower tier contractor management, as applicable, are responsible for promptly correcting problems found by independent assessments and ensuring corrective action is effective.

Independent assessment processes for Project W-460 shall comply with the applicable portions of QAPD Part 2, Section 10, Independent Assessment. 
5 References

Unless otherwise noted, the revisions will be the most current at time of preparation of this document.

BWHC, 1999, Project Execution Plan, Project 98L-EWW-460, Plutonium Stabilization and Handling, HNF-4681, Rev. A (Draft), B\&W Hanford Company, Richland, Washington.

DNFSB, 1994, Recommendation 94-1 to the Secretary of Energy, pursuant to 42 USC 2286 a(5) Atomic Energy Act of 1954, as amended, Defense Nuclear Facilities Safety Board, Washington, D.C.

DOE, 1996c, DOE-STD-3013-96, Criteria for Safe Storage of Plutonium Metals and Oxides, U. S. Department of Energy, Washington, D.C.

FDH, 1998, Project Hanford Management Contract, Project Hanford Policy and Procedure System Reference Map, HNF-MD-034, Revision 0, Fluor Daniel Hanford, Inc., Richland, Washington.

FDH, 1999, Project Hanford Management Contract, Project Hanford Quality Assurance Program Description, HNF-MP-599, Revision 3, Fluor Daniel Hanford, Inc., Richland, Washington.

FDH, 1997, Project Hanford Management Contract, Quality Assurance Program Plans, HNF-PRO-261, Revision 0, Fluor Daniel Hanford, Inc., Richland, Washington.

FDH, 1999, Functional Design Criteria for Project W-460, Plutonium Stabilization and Handling (PuSH), HNF-SD-W460-FDC-001, Rev. 1, Fluor Daniel Hanford Company, Richland, Washington.

FDH, 1997, Preliminary Safety Evaluation for Project W-460, Plutonium Stabilization and Handling (PuSH), HNF-SD-W460-PSE-001, Revision 0, Fluor Daniel Hanford Company, Richland, Washington.

FDH, 1998, Plutonium Finishing Plant Standards/Requirements Identification Document, HNF-SD-MP-SRID-003, Revision 1, Fluor Daniel Hanford Company, Richland, Washington.

FDH, 1999, Plutonium Finishing Plant Final Safety Analysis Report, HNF-SD-CP-SAR021, Rev. 1, August 2, 1999, Fluor Daniel Hanford Company, Richland, Washington.

FDNW, 1998, Facility Stabilization Project Execution Plan and Project Procedures Manual, B\&W Hanford Company, Facility Stabilization Project, Contract 651002, Revision 2, Fluor Daniel Northwest, Richland, Washington. 
United States Code of Federal Regulations 10 CFR 830.120, Nuclear Safety Management Quality Assurance, Washington, D.C. 


\section{ATTACHMENT A}

BASIC PROJECT STRUCTURES, SYSTEMS, AND COMPONENTS

\begin{tabular}{|c|c|c|c|c|c|c|}
\hline \multirow[t]{2}{*}{ ITEM ID } & \multirow{2}{*}{$\begin{array}{l}\text { STRUCTURE, SYSTEM, OR } \\
\text { COMPONENT } * *\end{array}$} & \multirow{2}{*}{$\begin{array}{l}\text { PRELIM. SAFETY } \\
\text { CLASSIFICATION }\end{array}$} & \multicolumn{3}{|c|}{$\begin{array}{l}\text { TYPE OF } \\
\text { INSPECTION }\end{array}$} & \multirow[t]{2}{*}{ COMMENTS } \\
\hline & & & $\mathrm{F}$ & $\mathrm{G}$ & $\mathrm{D}$ & \\
\hline 1 & 2736-Z and 2736-ZB Building Structures & SC & & & $\mathrm{X}$ & \\
\hline 2 & $\begin{array}{l}2736-Z \text { Building Vault Storage } \\
\text { Configuration }\end{array}$ & $\mathrm{SC}$ & & & $\mathrm{X}$ & \\
\hline 3 & $\begin{array}{l}\text { Glovebox Structures and applicable Floor } \\
\text { Anchors }\end{array}$ & SC & & & $\mathrm{X}$ & $\begin{array}{l}\text { Design, fabrication and installation criteria } \\
\text { for the gloveboxes shall be designated in } \\
\text { Procurement Specification Note: SC is for } \\
\text { Seismic consideration to prevent } \\
\text { Criticality. }\end{array}$ \\
\hline 4 & $\begin{array}{l}\text { Process Exhaust System HEPA Filters, } \\
\text { HEPA Filter Housing and Ductwork up to } \\
\text { 2736-ZB Roof Penetration }\end{array}$ & SC & & & $\mathrm{X}$ & \\
\hline 5 & $\begin{array}{l}\text { 2736-ZB Building Final HEPA Filters, } \\
\text { HEPA Filter Housing, and Ductwork from } \\
\text { the HEPA Filter Housing to the building } \\
\text { boundary }\end{array}$ & SC & & & $\mathrm{X}$ & \\
\hline 6 & $\begin{array}{l}2736-\mathrm{Z} \text { Building exhaust System HEPA } \\
\text { Filters, HEPA Filter Housing, and } \\
\text { Ductwork from the HEPA Filter Housing to } \\
\text { the building boundary }\end{array}$ & SC & & & $\mathrm{X}$ & \\
\hline 7 & $\begin{array}{l}\text { Vault Ventilation Supply Isolation Damper } \\
\text { and at } 2736 \mathrm{Z} \text { building boundary }\end{array}$ & $\mathrm{SC}$ & & & $\mathrm{X}$ & \\
\hline 8 & $\begin{array}{l}\text { Construction Opening on Outer Wall of } \\
2736-\mathrm{ZB}\end{array}$ & $\mathrm{SC}$ & & & $\mathrm{X}$ & \\
\hline 9 & $\begin{array}{l}\text { Cutting Tools and Electrical Equipment } \\
\text { Inside the Material Preparation Area }\end{array}$ & GS & $X$ & & & \\
\hline 10 & $\begin{array}{l}\text { Facility CAMs and Vautt Air Sampling } \\
\text { System }\end{array}$ & SS & $\mathrm{X}$ & & & \\
\hline 11 & $\begin{array}{l}\text { Furnace Cooling Jacket, IF Water Cooling is } \\
\text { used }\end{array}$ & SC & & & $\mathrm{X}$ & \\
\hline 12 & Moisture Detection in Gloveboxes & SS & $\mathrm{X}$ & & & \\
\hline 13 & Drier on Glovebox Supply Air & SS & $\mathrm{X}$ & & & \\
\hline 14 & Criticality Alarms & SS & $\mathrm{X}$ & & & \\
\hline 15 & $\begin{array}{l}\text { Glovebox Ventilation Kicker Fan and } \\
\text { Controls }\end{array}$ & GS & $\mathrm{x}$ & & & \\
\hline 16 & $\begin{array}{l}\text { Glovebox Confinement Boundary (e.g., } \\
\text { Windows, Gloveports, Sphincter Seals, } \\
\text { Entry Isolation Doors and their Controls) }\end{array}$ & SS & & & $\mathrm{X}$ & . \\
\hline 17 & Glovebox Pressure Indication and Alarms & GS & $\mathrm{X}$ & & & \\
\hline 18 & $\begin{array}{l}\text { SPE Dump Valves and Interlocks to } \\
\text { Glovebox Pressure Transducers }\end{array}$ & GS & $\mathrm{X}$ & & & \\
\hline 19 & $\begin{array}{l}\text { Regulators and Pressure Relief Valves } \\
\text { (PRVs) on Compressed Utility Gas Supplies } \\
\text { to BTS }\end{array}$ & GS & & $\mathrm{X}$ & & \\
\hline 20 & Restraints for fire stuppression gas bottles & SS or GS & & & $X$ & \\
\hline
\end{tabular}


HNF-SD-W460-QAPP-001

Rev. 1

\begin{tabular}{|c|c|c|c|c|c|c|}
\hline \multirow[t]{2}{*}{ ITEM ID } & \multirow{2}{*}{$\begin{array}{l}\text { STRUCTURE, SYSTEM, OR } \\
\text { COMPONENT ** }\end{array}$} & \multirow{2}{*}{$\begin{array}{l}\text { PRELIM. SAFETY } \\
\text { CLASSIFICATION }\end{array}$} & \multicolumn{3}{|c|}{$\begin{array}{c}\text { TYPE OF } \\
\text { INSPECTION } \\
\end{array}$} & \multirow[t]{2}{*}{ COMMENTS } \\
\hline & & & $\mathbf{F}$ & G & D & \\
\hline 21 & Separate Process Exhaust Stack & SS & & & $x$ & \\
\hline 22 & Stack Monitoring & SS & & $\mathbf{x}$ & & \\
\hline 23 & Calorimeters/Equilibration Bath & TBD & & $X$ & & \\
\hline 24 & Inner Can Welder/Equipment & TBD & & $\mathrm{X}$ & & Government Furnished Equipment \\
\hline 25 & Outer Can Welder & TBD & & $\mathrm{X}$ & & \\
\hline 26 & Radiographic Equipment & TBD & & $\mathrm{x}$ & & \\
\hline 27 & $\begin{array}{l}\text { Mechanical Can Handling Equipment (Hoist } \\
\text { System) }\end{array}$ & TBD & & & $\mathrm{x}$ & $\begin{array}{l}\text { Hanford Hoisting and Rigging Manual, if } \\
\text { applicable }\end{array}$ \\
\hline
\end{tabular}

\section{LEGEND:}

$\begin{array}{lll}\text { D } & \text { Detailed (Inspection) } & \text { See Attachment B } \\ \text { F } & \text { Functional (Inspection) } & \text { See Attachment B } \\ \text { G } & \text { General (Inspection) } & \text { See Attachment B } \\ \text { GS } & \text { General Service } & \\ \text { SC } & \text { Safety Class } & \\ \text { SS } & \text { Safety Significant } & \\ \text { TBD } & \text { To Be Determined } & \end{array}$

\section{NOTES:}

1. ** Information based upon the SSC identified in the Preliminary Safety Evaluation, HNF-SD-W460-PSE-001, Rev. 0. More explicit identification of Safety Classification for existing PFP Structures, Systems, or Components, the _Design Agent will utilize the information located in the PFP Safety Equipment List, HNF-SD-CP-TI-108, including all applicable revisions. Those components which are identified as TBD are not specifically classified by the PSE, in Revision 0 .

2. Unless Specified Otherwise, Remaining Structures, Systems, and/or Components are considered as General Service (e.g., Robotics for Handling/Transport of 3013 Containers, Modular Office Trailer: Including Structural Components, Utilities, etc.)

3. As a part of the overall Quality Assurance Program Plan, this Attachment will be modified, as required, at the next major revision to_incorporate changes in Structures, Systems, or Components and the applicable Safety Classification changes which will_occur during the course of this project. 


\section{ATTACHMENT B}

\section{TYPES OF INDEPENDENT VERIFICATION AND INSPECTION}

Specific rules covering all phases of inspection cannot be prescribed due to the variety and types of contracts and subcontracts, and the degree of responsibility assigned to the operating contractor, architect-engineer, construction contractors, and individual vendors. In general, inspection activities are divided into three categories: Functional, General and Detailed. As a part of the overall Quality Assurance Program Plan, this Attachment may require revision, which will be done at the next major revision to incorporate applicable changes encountered during the course of this project.

1. Functional Inspection. Performed to determine overall compliance with contract drawings and specifications. Functional Inspection may vary from inspection of minor items to extensive testing of operating equipment (which must be provided for in the contract). It may also serve in making initial determination of the adequacy of the design effort. The field element and the operating contractor participate in functional inspections from the viewpoints of owner and user.

2. General Inspection. The fundamental and comprehensive inspection to ascertain that workmanship and kind and quality of materials conform to the contract specifications.

3. Detailed Inspection. Includes, but is not limited to, verification of details, such as checking location and size of reinforcing bars, maintaining records of concrete batching operations, verifying the use of proper welding rods, checking riveting and welding, and performing other inspection for quality assurance purposes. Detailed inspections are carried out from initial construction operations and extend through all construction stages. 


\section{ATTACHMENT C \\ QUALITY ASSURANCE REQUIREMENTS MATRIX}

\begin{tabular}{|c|c|c|c|c|c|c|}
\hline \multirow{3}{*}{\multicolumn{2}{|c|}{$\begin{array}{c}\text { HNF-MP-599 } \\
\text { QAPD - } \\
\text { Part 2 } \\
\text { Requirements by Paragraph Including Keywords _ }\end{array}$}} & \multicolumn{5}{|c|}{ PROJECT PARTICIPANTS } \\
\hline & & \multirow{2}{*}{$\begin{array}{c}\text { PM } \\
\text { BWHC }\end{array}$} & \multirow{2}{*}{$\begin{array}{c}\text { A-E } \\
\text { FDNW }\end{array}$} & \multirow{2}{*}{$\begin{array}{c}\text { CM } \\
\text { FDNW }\end{array}$} & \multirow{2}{*}{$\begin{array}{c}\begin{array}{c}\text { Construction } \\
\text { Contractor }\end{array} \\
\text { FDNW/Fixed Price }\end{array}$} & \multirow{2}{*}{ Procurement } \\
\hline & & & & & & \\
\hline \multicolumn{7}{|l|}{ Stchon } \\
\hline $3.1 * *$ & Structure, QA Program & & & & & \\
\hline 3.2 & QA Procedures & $\checkmark$ & & & & \\
\hline 3.3 .1 & \multirow[t]{5}{*}{ QA Program Plans } & $\checkmark$ & & & & \\
\hline 3.3 .2 & & 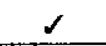 & $\checkmark$ & $\checkmark$ & $\checkmark$ & \\
\hline 3.3 .3 & & $\checkmark$ & 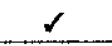 & $\checkmark$ & $\checkmark$ & $\checkmark$ \\
\hline $3.3 .4 * *$ & & & & & & \\
\hline 3.3 .5 & & $\checkmark$ & $\checkmark$ & $\checkmark$ & $\checkmark$ & $\checkmark$ \\
\hline $3.4 .1^{* *}$ & \multirow[t]{2}{*}{ QA Requirements Flowdown } & & & & & \\
\hline 3.4 .2 & & $\checkmark$ & $\checkmark$ & $\checkmark$ & $\checkmark$ & $\checkmark$ \\
\hline 3.5 & Quality Planning & $\checkmark$ & & & & \\
\hline 3.6 .1 & \multirow[t]{3}{*}{ Organization, Responsibilities, Interfaces } & $\checkmark$ & $\checkmark$ & 1 & $\checkmark$ & $\checkmark$ \\
\hline 3.6 .2 & & $\checkmark$ & $\checkmark$ & $\checkmark$ & 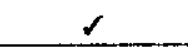 & $\checkmark$ \\
\hline 3.6 .3 & & $\checkmark$ & & & & \\
\hline 3.7 & Readiness Review & 2 & & & & \\
\hline 3.8 .1 & \multirow[t]{2}{*}{ Stop Work Authority } & $\checkmark$ & $\checkmark$ & $\checkmark$ & $\checkmark$ & $\checkmark$ \\
\hline 3.8 .2 & & $\checkmark$ & & 6 & & \\
\hline 3.9 .1 & \multirow[t]{6}{*}{ Graded Application } & $\checkmark$ & $\checkmark$ & $\checkmark$ & $\checkmark$ & $\sigma_{-}$ \\
\hline 3.9 .2 (all) & & $\checkmark$ & $\checkmark$ & $\checkmark$ & $\checkmark$ & $\therefore$ \\
\hline 3.9 .3 & & $\checkmark$ & $\checkmark$ & $\checkmark$ & $\checkmark$ & $\checkmark$ \\
\hline 3.9 .4 & & 6 & 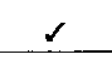 & $\checkmark$ & 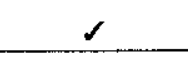 & $\sigma_{-}$ \\
\hline 3.9 .5 & & $\checkmark$ & & & & \\
\hline 3.9 .6 & & $\checkmark$ & & & & \\
\hline \multicolumn{7}{|l|}{ StenoN } \\
\hline 3.1 & Training and Qualification Program & $\checkmark$ & & & & \\
\hline 3.2 .1 & \multirow[t]{4}{*}{ Training and Indoctrination } & $\checkmark$ & 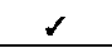 & $\checkmark$ & $\checkmark$ & $\sigma_{-}$ \\
\hline 3.2 .2 & & $\checkmark$ & $\checkmark$ & $\checkmark$ & $\checkmark$ & $\sigma_{-}$ \\
\hline 3.2 .3 & & & & & & \\
\hline 3.2 .4 & & $\checkmark$ & $\checkmark$ & 6 & $\checkmark$ & $\checkmark$ \\
\hline 3.3 .2 & \multirow[t]{2}{*}{ Qualification and Certification } & $\checkmark$ & $\checkmark$ & $\checkmark$ & $\checkmark$ & $\checkmark$ \\
\hline 3.3 .3 & & & $\checkmark$ & & $\checkmark$ & $\checkmark$ \\
\hline
\end{tabular}


Rev. 1

\begin{tabular}{|c|c|c|c|c|c|c|}
\hline \multirow{3}{*}{\multicolumn{2}{|c|}{$\begin{array}{c}\text { HNF-MP-599 } \\
\text { QAPD - } \\
\text { Part 2 } \\
\text { Requirements by Paragraph Including Keywords }\end{array}$}} & \multicolumn{5}{|c|}{ PROJECT PARTICIPANTS } \\
\hline & & \multirow{3}{*}{$\begin{array}{c}\text { PM } \\
\text { BWHC }\end{array}$} & \multirow{2}{*}{$\begin{array}{c}\text { A-E } \\
\text { FDNW }\end{array}$} & \multirow{2}{*}{$\begin{array}{c}\text { CM } \\
\text { FDNW }\end{array}$} & \multirow{2}{*}{$\begin{array}{c}\begin{array}{c}\text { Construxtion } \\
\text { Contrator of }\end{array} \\
\text { FDNW/Fixed Price }\end{array}$} & \multirow{2}{*}{ Procurement } \\
\hline & & & & & & \\
\hline 3.3 .4 & (cont) Qualification and Certification & & 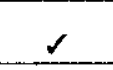 & & $\checkmark$ & $\checkmark$ \\
\hline 3.4 & Training and Qualification Records & $\checkmark$ & 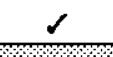 & $\checkmark$ & $\checkmark$ & $\checkmark$ \\
\hline \multicolumn{7}{|c|}{ 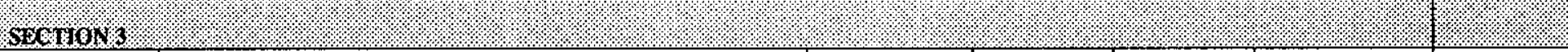 } \\
\hline 3.1 .1 & \multirow[t]{2}{*}{ Deficiency Identification } & 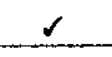 & $\checkmark$ & $\checkmark$ & $\checkmark$ & $\checkmark . .$. \\
\hline 3.1 .2 & & & & & & \\
\hline 3.2 .1 & \multirow[t]{3}{*}{ Corrective Action Management } & $\checkmark$ & $\checkmark$ & $\checkmark$ & $\checkmark$ & \\
\hline 3.2 .2 & & $\checkmark$ & $r$ & $\checkmark$ & $\checkmark$ & \\
\hline 3.2 .3 & & 1 & & & & \\
\hline 3.3 .1 & \multirow[t]{9}{*}{ Nonconformance Control } & $\checkmark$ & & $\checkmark$ & $\checkmark$ & $\checkmark$ \\
\hline 3.3 .2 & & $\checkmark$ & & 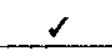 & $\checkmark$ & $\checkmark$ \\
\hline 3.3 .3 & & $\checkmark$ & & $\checkmark$ & $\checkmark$ & $\checkmark$ \\
\hline 3.3 .4 & & $\checkmark$ & & $\checkmark$ & 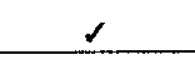 & 8 \\
\hline 3.3 .5 & & $\checkmark$ & $\checkmark$ & $\checkmark$ & $\checkmark$ & $\checkmark$ \\
\hline 3.3 .6 & & $\checkmark$ & $\checkmark$ & $\checkmark$ & 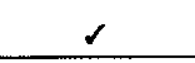 & $\checkmark$ \\
\hline 3.3 .7 & & $\checkmark$ & & $\checkmark$ & $\checkmark$ & $\therefore$ \\
\hline 3.3 .8 & & $\checkmark$ & & $\checkmark$ & $\checkmark$ & $\alpha_{.}$ \\
\hline 3.3.9 & & $\checkmark$ & & $\checkmark$ & $\checkmark$ & $\checkmark$ \\
\hline $3.4 .1^{* *}$ & \multirow[t]{6}{*}{ Performance Data Analysis } & & & & & \\
\hline $3.4 .2 * *$ & & & & & & \\
\hline $3.4 .3 * *$ & & & & & & \\
\hline 3.4 .4 & & $\checkmark$ & & & & \\
\hline 3.4 .5 & & $\checkmark$ & & & & \\
\hline 3.4 .6 & & $\checkmark$ & & & & \\
\hline \multicolumn{7}{|c|}{580110414} \\
\hline 3.0 & Documents and Records & $\checkmark$ & & & & \\
\hline 3.1 .1 & \multirow[t]{5}{*}{ Documents } & 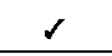 & $\checkmark$ & $s$ & $\checkmark$ & $s_{-}$ \\
\hline 3.1 .2 & & $s$ & 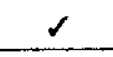 & $\checkmark$ & $\checkmark$ & $\checkmark_{-}$ \\
\hline 3.1 .3 & & $\checkmark$ & $\checkmark$ & $\checkmark$ & $s$ & $\checkmark$ \\
\hline 3.1 .4 & & $\checkmark$ & $\checkmark$ & $\checkmark$ & $\checkmark$ & 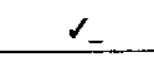 \\
\hline 3.1 .5 & & & $\checkmark$ & & & \\
\hline 3.2 .1 & \multirow[t]{2}{*}{ Records } & $\checkmark$ & $\checkmark$ & 1 & 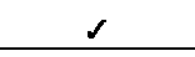 & $\checkmark$ \\
\hline 3.2 .2 & & & & $\checkmark$ & $\checkmark$ & $\checkmark$ \\
\hline
\end{tabular}




\begin{tabular}{|c|c|c|c|c|c|c|}
\hline \multirow{3}{*}{\multicolumn{2}{|c|}{$\begin{array}{c}\text { HNF-MP-599 } \\
\text { QAPD_- } \\
\text { Part 2 } \\
\text { Requirements by Paragraph Including Keywords _ }\end{array}$}} & \multicolumn{5}{|c|}{ PROJECT PARTICIPANTS } \\
\hline & & \multirow{2}{*}{$\begin{array}{c}\text { PM } \\
\text { BWHC }\end{array}$} & \multirow{2}{*}{$\begin{array}{c}\text { A-E } \\
\text { FDNW }\end{array}$} & \multirow{2}{*}{$\begin{array}{l}\text { CM } \\
\text { FDNW }\end{array}$} & \multirow{2}{*}{$\begin{array}{c}\begin{array}{c}\text { Construction } \\
\text { Contractor }\end{array} \\
\text { FDNW/Fixod Prios }\end{array}$} & \multirow{2}{*}{ Procurement } \\
\hline & & & & & & \\
\hline 3.2 .3 & \multirow[t]{3}{*}{ (cont) Records } & $\checkmark$ & $\checkmark$ & $\checkmark$ & 6 & $\therefore$ \\
\hline 3.2 .4 & & 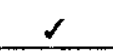 & & & & \\
\hline 3.2 .5 & & & $\checkmark$ & & $\checkmark$ & $\checkmark \ldots$ \\
\hline \multicolumn{7}{|c|}{ Sicrion: } \\
\hline 3.1 .1 & \multirow[t]{5}{*}{ Work Process Documents } & & & & & \\
\hline 3.1 .2 & & & 6 & 6 & $\checkmark$ & $r$ \\
\hline 3.1 .3 & & & & $r$ & $a$ & $\mathrm{~s}$ \\
\hline 3.1 .4 & & & $\checkmark$ & 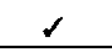 & 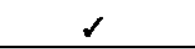 & $s$ \\
\hline 3.1 .5 & & & $\checkmark$ & $\checkmark$ & 1 & $\checkmark$ \\
\hline 3.2 & Special Processes & & & & $r$ & $\therefore$ \\
\hline 3.3 .1 & \multirow[t]{3}{*}{ Identification and Control of Items } & & & $\checkmark$ & 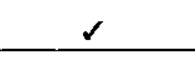 & $\checkmark$ \\
\hline 3.3 .2 & & & & $\checkmark$ & $\checkmark$ & $\checkmark .$. \\
\hline 3.3.3 & & & & $\checkmark$ & 6 & $\checkmark$ \\
\hline 3.4 .1 & \multirow[t]{3}{*}{ Handling, Shipping, and Storing } & & & $s$ & $r$ & $\checkmark$ \\
\hline 3.4 .2 & & & & $\checkmark$ & 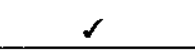 & S... \\
\hline 3.4 .3 & & & & $\checkmark$ & $\checkmark$ & $\checkmark$ \\
\hline 3.5 & Process Monitoring or Data Collection Instruments & & & & & \\
\hline 3.6 & Control of Computer Software & $\checkmark$ & $\therefore$ & $\checkmark$ & 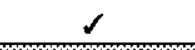 & $\checkmark$. \\
\hline \multicolumn{7}{|c|}{ SeCHON 6} \\
\hline 3.1 & \multirow[t]{4}{*}{ Design Input } & $\checkmark$ & $\checkmark$ & & & 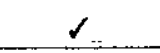 \\
\hline 3.1 .1 & & $s$ & 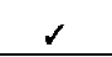 & & & 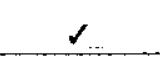 \\
\hline 3.1 .2 & & $\checkmark$ & $\checkmark$ & & & $\checkmark$ \\
\hline 3.1 .3 & & 6 & $\checkmark$ & & & $\checkmark$ \\
\hline 3.2 .1 & \multirow[t]{10}{*}{ Design Process } & $\checkmark$ & $\checkmark$ & & & $\therefore$ \\
\hline 3.2 .2 & & $\checkmark$ & $\checkmark$ & & & $s$ \\
\hline 3.2 .3 & & $\checkmark$ & 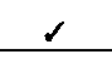 & & & 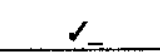 \\
\hline 3.2 .4 & & $\checkmark$ & & & & \\
\hline 3.2 .5 & & $\checkmark$ & $\checkmark$ & $\checkmark$ & $\checkmark$ & $\therefore$ \\
\hline 3.2 .6 & & 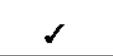 & 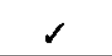 & & & $s_{-}$ \\
\hline 3.2 .7 & & 1 & 1 & & & $\checkmark$ \\
\hline 3.2 .8 & & $\checkmark$ & 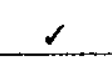 & & & $\sigma_{-}$ \\
\hline 3.2 .9 & & $\checkmark$ & 1 & & & $\therefore$ \\
\hline 3.2 .10 & & $\checkmark$ & $\checkmark$ & & & $r_{-}$ \\
\hline
\end{tabular}


Rev. 1

\begin{tabular}{|c|c|c|c|c|c|c|}
\hline \multirow{3}{*}{\multicolumn{2}{|c|}{$\begin{array}{c}\text { HNF-MP-599 } \\
\text { QAPD - } \\
\text { Part 2 } \\
\text { Requirements by Paragraph Including Keywords }\end{array}$}} & \multicolumn{5}{|c|}{ PROIECT PARTICIPANTS } \\
\hline & & \multirow{2}{*}{$\begin{array}{c}\text { PM } \\
\text { BWHC }\end{array}$} & \multirow{2}{*}{$\begin{array}{c}\text { A-E } \\
\text { FDNW }\end{array}$} & \multirow{2}{*}{$\begin{array}{c}\text { CM } \\
\text { FDNW }\end{array}$} & \multirow{2}{*}{$\frac{\begin{array}{c}\text { Construction } \\
\text { Contractor }\end{array}}{\text { FDNW/Fixod Price }}$} & \multirow{2}{*}{ Procurement } \\
\hline & & & & & & \\
\hline 3.2 .11 & (con't) Design Process & $\checkmark$ & $\checkmark$ & & & $\checkmark$ \\
\hline 3.3 .1 & \multirow[t]{4}{*}{ Design Verification } & $\checkmark$ & $\checkmark$ & & & $\checkmark \ldots$ \\
\hline 3.3 .2 & & $\checkmark$ & $\checkmark$ & & & $\checkmark$. \\
\hline 3.3 .3 & & $\checkmark$ & $\checkmark$ & & & $\checkmark$. \\
\hline 3.3 .4 & & $\checkmark$ & $\checkmark$ & & & $\checkmark$ \\
\hline 3.4 .1 & \multirow[t]{2}{*}{ Design Changes } & $\checkmark$ & $\checkmark$ & $\checkmark$ & $\checkmark$ & $\checkmark \ldots$ \\
\hline 3.4 .2 & & $\checkmark$ & $\checkmark$ & $\checkmark$ & $\checkmark$ & $\checkmark$ \\
\hline 3.5 & Design Documentation and Records & $\checkmark$ & $\checkmark$ & & & $\checkmark$ \\
\hline 3.6 & Computer Software & $\checkmark$ & $\checkmark$ & & $\checkmark$ & $\checkmark$ \\
\hline \multicolumn{7}{|c|}{ SERTON\% } \\
\hline 3.1 & Procurement Planning. & $\checkmark$ & $\checkmark$ & $\checkmark$ & $\checkmark$ & $\checkmark$. \\
\hline 3.2 .1 & \multirow[t]{3}{*}{ Content of Procurement Documents } & $\checkmark$ & $\checkmark$ & $\checkmark$ & $\checkmark$ & $\checkmark$ \\
\hline 3.2 .2 & & $\checkmark$ & $\therefore$ & $\therefore$ & $\checkmark$ & $\checkmark$ \\
\hline 3.2 .3 & & $\checkmark$ & $\checkmark$ & $\checkmark$ & $\checkmark$ & $\checkmark$ \\
\hline 3.3 .1 & \multirow[t]{4}{*}{ Supplier Evaluation and Selection } & $\checkmark$ & $\checkmark$ & $\checkmark$ & $\checkmark$ & $\checkmark \ldots$ \\
\hline 3.3 .2 & & $\checkmark$ & $\checkmark$ & $\checkmark$ & $\checkmark$ & $\underline{-}$ \\
\hline 3.3 .3 & & $\checkmark$ & $\checkmark$ & $\checkmark$ & $\checkmark$ & $\checkmark \ldots$ \\
\hline 3.3 .3 & & $\checkmark$ & $\checkmark$ & $\checkmark$ & $\checkmark$ & $\checkmark$ \\
\hline 3.4 & Control of Supplier Nonconformance & $\checkmark$ & $\checkmark$ & $\checkmark$ & $\therefore$ & $\checkmark$ \\
\hline 3.5 .1 & \multirow[t]{2}{*}{ Acceptance of Items and Services } & $\checkmark$ & $\checkmark$ & $\checkmark$ & $\checkmark$ & $\checkmark$ \\
\hline 3.5 .2 & & $\checkmark$ & $\checkmark$ & $\checkmark$ & $\checkmark$ & $\checkmark$ \\
\hline 3.6 & \multirow[t]{3}{*}{ Commercial Grade Items } & $\checkmark$ & $\checkmark$ & $\checkmark$ & $\checkmark$ & $\checkmark$ \\
\hline 3.6 .1 & & $\checkmark$ & $\checkmark$ & $\checkmark$ & $\checkmark$ & 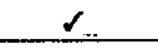 \\
\hline 3.6 .2 & & $\checkmark$ & $\checkmark$ & $\checkmark$ & $\checkmark$ & $\checkmark$ \\
\hline 3.7 & Control of Supplier-Generated Documents & $\checkmark$ & $\checkmark$ & $\checkmark$ & $\checkmark$ & $\checkmark$ \\
\hline \multicolumn{7}{|c|}{$\mathrm{SBC} M \mathrm{MO} 8$} \\
\hline 3.1 .1 & \multirow[t]{2}{*}{ Inspection and Acceptance Testing Planning } & $\checkmark$ & $\checkmark$ & $\checkmark$ & $\checkmark$ & $\checkmark$ \\
\hline 3.1 .3 & & $\checkmark$ & $\checkmark$ & $\checkmark$ & $\checkmark$ & $\checkmark$. \\
\hline 3.2 .1 & \multirow[t]{2}{*}{ Inspection and Acceptance Testing Process } & $\checkmark$ & $\checkmark$ & & $\checkmark$ & $\checkmark$. \\
\hline 3.2 .2 & & $\checkmark$ & $\checkmark$ & & $\checkmark$ & $\checkmark \ldots$ \\
\hline 3.3 & Inspection and Acceptance Testing Records & $\checkmark$ & $\checkmark$ & & $\checkmark$ & $\checkmark$ \\
\hline 3.4 & Inspection and Acceptance Testing Status & & & & $\checkmark$ & \\
\hline 3.5 & Calibration of Measuring and Test Equipment & $\checkmark$ & $\checkmark$ & & $\checkmark$ & $\checkmark$ \\
\hline
\end{tabular}




\begin{tabular}{|c|c|c|c|c|c|c|}
\hline \multirow{3}{*}{\multicolumn{2}{|c|}{$\begin{array}{c}\text { HNF-MP-599 } \\
\text { QAPD - } \\
\text { Part 2 } \\
\text { Requirements by Paragraph Including Keywords _ }\end{array}$}} & \multicolumn{5}{|c|}{ PROJECT PARTICIPANTS } \\
\hline & & \multirow{2}{*}{$\begin{array}{l}\text { PM } \\
\text { BWHC }\end{array}$} & \multirow{2}{*}{$\begin{array}{c}\text { A-E } \\
\text { FDNW }\end{array}$} & \multirow{2}{*}{$\begin{array}{l}\text { CM } \\
\text { FDNW }\end{array}$} & $\begin{array}{c}\text { Conetruction } \\
\text { Contractor } \\
\end{array}$ & \multirow{2}{*}{ Procurement } \\
\hline & & & & & FDNW/Fixed Price & \\
\hline \multicolumn{7}{|c|}{$801104 \%$} \\
\hline 3.1 (all) & Management Assessments & $\checkmark$ & $\checkmark$ & $\checkmark$ & $\checkmark$ & $\checkmark$ \\
\hline 3.2 & Corrective Actions & $\checkmark$ & $\checkmark$ & $\checkmark$ & $\checkmark$ & $\checkmark$ \\
\hline \multicolumn{7}{|c|}{ S1CW10N 10} \\
\hline 3.1 .1 & \multirow[t]{2}{*}{ Focus of Independent Assessments } & $\checkmark$ & & & & \\
\hline 3.1 .2 & & $\checkmark$ & & & & \\
\hline 3.2 .1 & \multirow[t]{3}{*}{ Performance of Independent Assessments } & $\checkmark$ & & & & \\
\hline 3.2 .2 & & 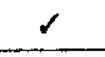 & & & & \\
\hline 3.2 .3 & & $\checkmark$ & & & & \\
\hline
\end{tabular}

\section{Notes:}

1) Paragraph references which are missing from Matrix have been determined to not have applicable requirements, hence they have been eliminated.

2) Items identified with "**" have been determined to apply at a higher level and will not apply at the Project level.

3) Related Standard (ASME NQA-1, Nuclear Quality Assurance) may be used as a Guide for applying the specific QA Programmatic requirements.

4) The use of the Matrix is as a Guide towards applying Quality Requirements to Safety Class Items. The Graded Approach shall be used for these features, as determined by the particular structure, system, or component involved. Further evaluation by a Graded Approach is to be used when evaluating Quality Requirements to be applied to Safety Significant or General Service structures, systems, or components.

5) As a part of the overall Quality Assurance Program Plan, this Attachment will be modified, as required, at the next major revision to incorporate any required changes which occur during the course of this project. 
웡

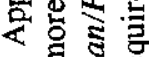

$\rightarrow$ 政

는

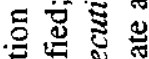

Uु

乎

궁

है

宅

$\infty$ 응

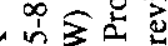

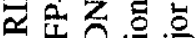

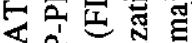

$\sum$ 的

A

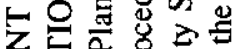

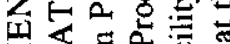

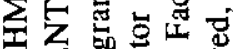

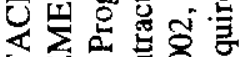

响

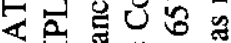

部荡淢

定崖

象 0

苨氙记

茅勇

它

然

留

话氛家

声总总兽

苛苛吾

实

可范

넌인

客造

官菏

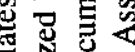

产

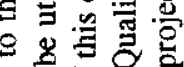

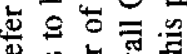

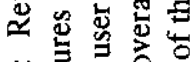

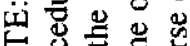

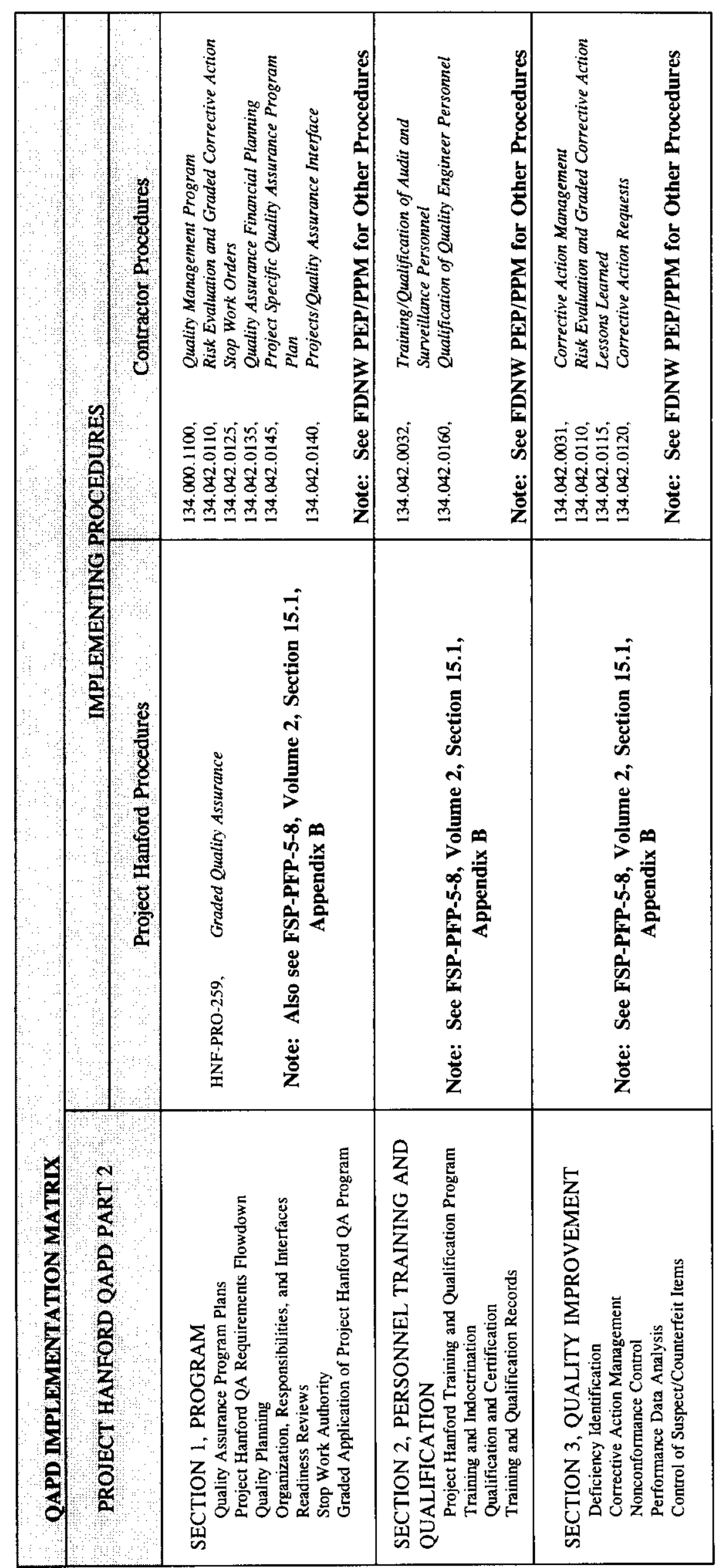




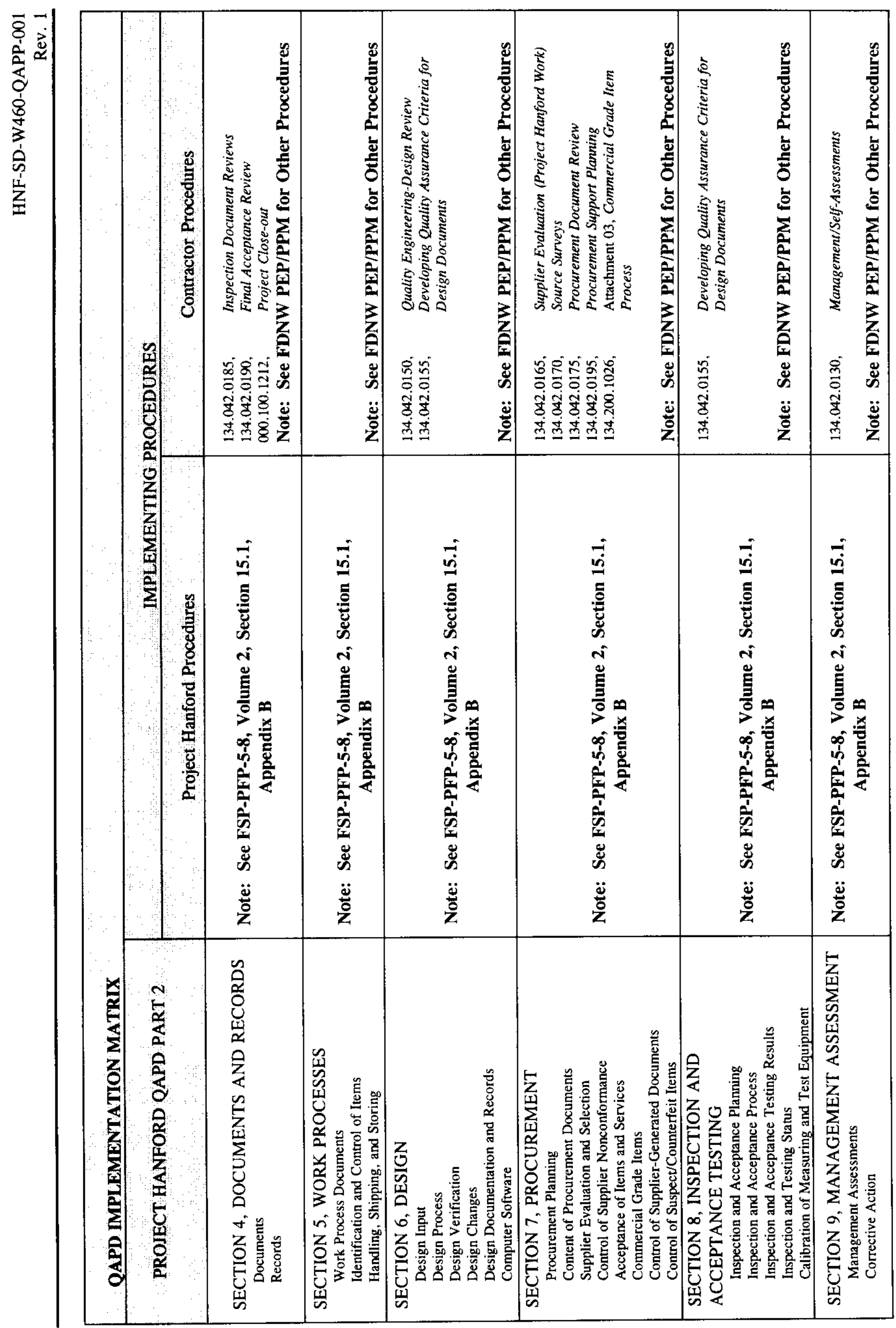

